\title{
The Correlation between the Pool of Free Adhesion Molecule Receptors and the Activity of the Immune System in the Murmansk Oblast Residents
}

\author{
A. V. Samodova ${ }^{a, *}$ and L. K. Dobrodeeva ${ }^{a}$ \\ ${ }^{a}$ Laverov Institute of Physiology of Natural Adaptations, Federal Research Center for Integrated Study of the Arctic, \\ Russian Academy of Sciences, Arkhangelsk, Russia \\ *e-mail: annapoletaeva2008@yandex.ru
}

Received October 3, 2017; revised December 27, 2017; accepted March 21, 2018

\begin{abstract}
The molecules of intercellular adhesion are the surface cellular glycoproteins responsible for interaction between cells of different types with one another and with the components of intercellular matrix. They play the primary role in the formation of tissue structure and participate in a number of physiological processes, such as morphogenesis, embryogenesis, organogenesis, wound healing, and inflammation. Together with the other free receptors and their ligands, free intercellular adhesion molecules are formed mainly through shedding, resulting from the proteolytic cleavage of the transmembrane region under physiological conditions or cell destruction. There are almost no literature data on the influence of free intercellular adhesion molecules on the functional activity of T and B lymphocytes and the contents of immunoglobulins, cytokines, and circulating immune complexes. Therefore, the purpose of this study was to identify the interrelationship between the content of free and membrane-bound intercellular adhesion molecules and the level of immunocompetent cell activity in the residents of the Arctic settlement of Revda (Murmansk oblast), who form one of special populations of residents living in the Arctic region of the Russian Federation. It has been found that the contents of sCD54, sCD62L, and sCD324 free intercellular adhesion molecules vary widely, which results from an increase in the concentration of cells with the corresponding membrane forms. An increase in the levels of sCD54 and sCD62 is accompanied by the activation of migration processes with increasing concentrations of circulating neutrophils and total lymphocyte count. The formation of a pool of membrane-bound and free adhesion molecules occurs together with an increase in the content of activated T cells of the HLADRII and CD $8+$ phenotypes. An increase in the serum levels of sCD54 and L-selectin (sCD62L) adhesion molecules is accompanied by a decrease in the level of immunocompetent cell activity and a twofold increase in the serum level of a natural immunosuppressant IL-10. Low activity of the sCD54 and $\mathrm{SCD} 62 \mathrm{~L}$ is associated with an increase in the $\mathrm{IgE}$ concentration and in immune responses caused by the basophil and eosinophil activation.
\end{abstract}

Keywords: free and membrane-bound intercellular adhesion molecules, sCD54, sCD62L, sCD324, neutrophils, lymphocytes, activated T-lymphocytes, cytotoxic T-lymphocytes, IL-10, IgE

DOI: $10.1134 / \mathrm{S} 0362119718060105$

Intercellular adhesion molecules are the cell surface glycoproteins responsible for cellular interaction and interaction between cells and intercellular matrix. Intercellular adhesion molecules include selectin, immunoglobulin, integrin, cadherin, and homing receptor superfamilies. They play a major role in the formation of tissue structure and also participate in a number of physiological processes, including morphogenesis, embryogenesis, organogenesis, wound healing, and inflammation $[1,2]$. For example, $E$ cadherin (sCD324) acts as a transmembrane receptor which contributes to calcium-dependent cellular interactions and signaling [3]. $L$-selectin (sCD62L) provides the first phase (rolling) of migration of the cells into the tissues after fixation of a blood cell with heparin sulfate of the endothelial cell membrane. Then, the activation of chemokine receptors leads to the conformational changes in integrins with their subsequent binding to the ligands on the endothelial surface. During rolling, the leukocytes adhere to the vessel wall and then roll along the endothelial lining until they receive extracellular signals which trigger transendothelial migration into tissues $[4,5]$. Under physiological conditions, rolling on selectins is a precondition for the formation of more dense adhesion by binding through integrins. Selectins are located at the tips of the leukocyte membrane folds; in response to cytokine and inflammation mediator stimulation, selectins are rapidly shed from the cell surface upon activation via the $\mathrm{Ca}^{2+}$-dependent protein cleavage; 
concurrently, the efficiency of adhesion through the $\beta_{2}$-integrins increases [6-9].

Free intercellular adhesion molecules, as well as other free receptors and their ligands, are mainly formed by shedding as a result of proteolytic cleavage of the transmembrane region under the physiological conditions or cell destruction [10-12].

The extracellular pool of signal molecules, receptors, and ligands may maintain a functional capacity of responding to a corresponding substrate without signal transduction into the cell by binding and inactivating biologically active substances. Free receptor forms, including adhesion molecules, can interact with membrane ligands, block cell contacts, inhibit cell migration and recirculation, thereby limiting intercellular communication in the immune response $[13,14]$. Free molecules circulate mainly as molecular complexes, which not only provide their neutralization, but also protect them from proteolytic degradation [12, 15-17]. The circulating complexes of adhesion molecules and their ligands can dissociate, thus providing the contact interaction of the biologically active components while preserving their specific properties and functional activity and temporarily neutralizing or even pooling the complex [13, 14].

Shedding can be viewed as a necessity of receptor turnover or as a consequence of a decreased functional demand for a particular substrate, or its purpose may be to increase the receptor concentration in the intracellular space in order to provide paracrine regulation, which is quite ambiguous except for antibody formation. In fact, the antibody formation is a secretion of the substances with relatively specific structure which does not contain a membrane domain. Shedding of the receptors is also a way of receptor turnover, which has already been proven for insulin receptors [18, 19], thyroid hormones, adrenocorticotropic hormone (ACTH), and IL-2 [20]. It has not yet been determined whether there is a signal molecule for the turnover and what the role of shedding in the development of the cooperative immune response accompanied by proliferation, differentiation, and apoptosis of the immunocompetent cells is.

There are almost no data on the influence of free intracellular adhesion molecules on the T- and Blymphocyte functional activity, immunoglobulin and cytokine contents, and circulating immune complexes. We have obtained data on the possible role of free circulating adhesion molecules in antigen presentation and T-lymphocyte activation and apoptosis [21, 22].

Therefore, the goal of the present study was to investigate a correlation between the content of free and membrane-bound intercellular adhesion molecules and the level of immunocompetent cell activity in residents of the Revda settlement of the Murmansk oblast.

\section{METHODS}

A group of 174 volunteers aged 21-55 years residing in the Revda settlement of the Levozersky raion of the Murmansk oblast (141 women and 33 men) were selected for the examination.

The immunological research complex included the analysis of hemogram and phagocytic activity of peripheral blood neutrophils. The phenotypes of peripheral blood lymphocytes (CD16+, CD45RA, CD3+, $\quad$ CD71+, CD25+, HLA DR+, $\mathrm{CD} 10+, \mathrm{CD} 19+, \mathrm{CD} 23+, \mathrm{CD} 4+$, and CD8+) and mononuclear cells with the CD54 adhesion molecule (ICAM-1, free intercellular adhesion molecule 1 of the immunoglobulin superfamily), E-cadherin CD324 (E-Cad), and selectin (CD62L) membrane receptors were investigated using the indirect immunoperoxidase method (an assay kit manufactured by Sorbent, Moscow, Russia). The contents of IgA, IgM, IgG, and IgE and cytokines IL-2, IL-6, IL-10, IFN$\gamma, \mathrm{sCD} 54$, and sCD324 (E-cadherin, E-Cad), and sLselectin (sCD62L) were determined in the blood serum by the enzyme-linked immunosorbent assay (ELISA) technique using the Seramnum Diagnostica (Germany), Bender Medsystems (Austria), and Elisa Kit (China) reagents. The reaction was assessed using an Evolis automated enzyme-immunoassay analyzer (Bio-RAD, Germany). The level of circulating immune complexes (CICs) was determined by the standard precipitation method using the $3.5 \%, 4 \%$, and $7.5 \%$ of polyethylene glycol (PEG) with a molecular weight of $6000 \mathrm{Da}$.

To study the correlation between intercellular adhesion molecule contents and immune response level, the initial values in the database were divided into the samples with low and high contents of free and membrane-bound molecules and selectin. To perform a statistical transformation and eliminate asymmetry of the initial analysis variables, the data were presented in the logarithmic form $(\log )$. Mathematical and statistical analyses of the results were performed by means of an IBM/AT-Pentium 4 computer using the Microsoft Excel 2010 (United States) and Statistica 7.0 (StatSoft, United States) applied software packages. For each of the indices described, the parameters of descriptive statistics $(M$, arithmetic mean value; $\sigma$, standard deviation; $m$, standard error of the mean; $M d$, median; $R$, range; $W$, coefficient of variation; and 95\% confidence limit) were calculated for all free to membrane-bound receptor content ratios. The distribution of immunological index values was assessed using Pearson's test. The null hypothesis on the equality of the mean values in the groups was tested using one-way analysis of variance (ANOVA). If the data distribution was not normal, the variables in two different groups were compared using the nonparametric Mann-Whitney $U$ test. The differences were considered statistically significant at $p<0.05$. 

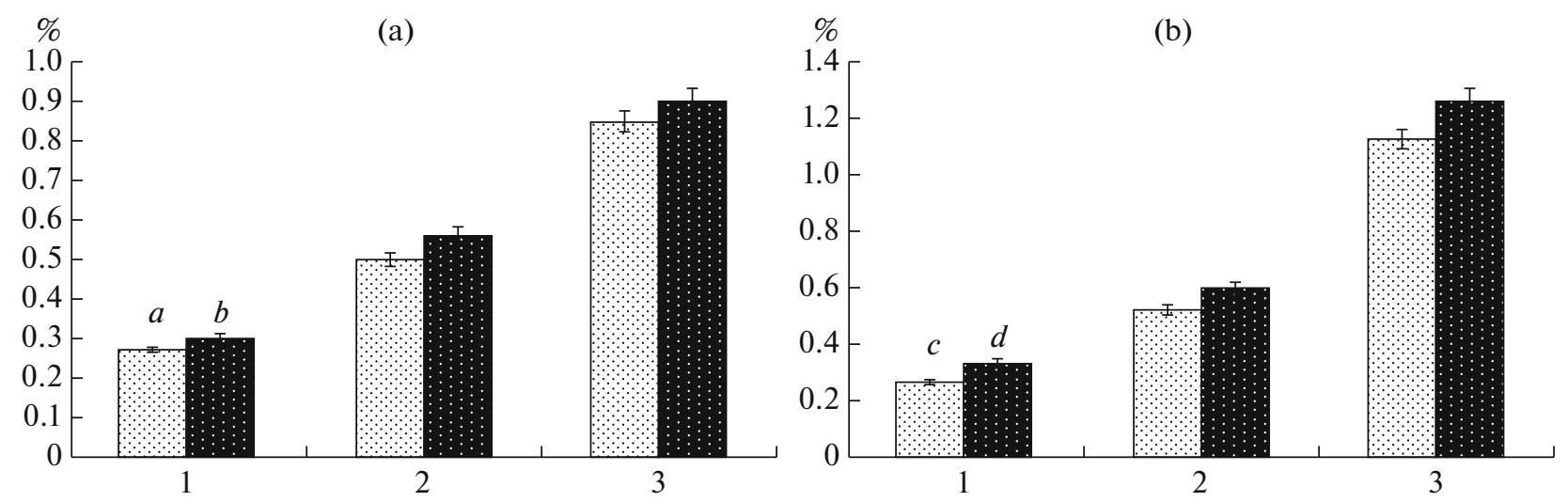

Fig. 1. The degree of an increase in the content of membrane-bound and free intercellular adhesion molecules: (a) mCD54 and sCD54; (b) mCD62L and sCD62L. The abscissa shows the level of membrane-bound and free intercellular adhesion molecules: 1, low level; 2, medium level; 3, high level; $a$, mCD54; $b$, sCD54; $c$ mCD62L; $d$, sCD62L.

\section{RESULTS}

It has been confirmed that the content of free intercellular adhesion molecules, as well as the level of other free molecules, such as SCD23, sCD25, sCD71, sCD80, sAPO-1/Fas, and sFasL, vary widely [21]. For example, the highest concentrations were observed for the free sCD54 molecule of the type I immunoglobulin superfamily sCD54 (216.88 \pm 9.75 on average; ranging from $133.46 \pm 5.25$ to $290.88 \pm 9.90 \mathrm{ng} / \mathrm{mL}$ ); the level of free selectin ligand SCD62L was considerably lower $(8.44 \pm 0.76$; range from $3.85 \pm 0.41$ to $14.36 \pm 1.82 \mathrm{ng} / \mathrm{mL}$ ); free calcium-dependent cell adhesion protein sCD324 was observed in the lowest concentration $(0.51 \pm 0.04 \mathrm{ng} / \mathrm{mL}$; ranging from $0.16 \pm 0.02$ to $0.89 \pm 0.04 \mathrm{ng} / \mathrm{mL}$ ).

An increase in the content of free intercellular adhesion molecules goes together with an increase in the blood level of the corresponding lymphocytes containing the membrane-bound form of a giver receptor. For example, when the serum sCD54 concertation increases (from $133.46 \pm 5.25$ to $290.88 \pm$ $9.90 \mathrm{ng} / \mathrm{mL}$ ), the level of $\mathrm{mCD} 54$ also rises (from $0.27 \pm 0.01$ to $0.85 \pm 0.08 \times 10^{9}$ cell $\left./ \mathrm{L} ; p<0.001\right)$, and the level of $\mathrm{mCD} 62 \mathrm{~L}$ increases (from $0.26 \pm 0.04$ to $1.12 \pm 0.17 \times 10^{9}$ cell $\left./ \mathrm{L} ; p<0.001\right)$ together with the rise in free lectin ligand concentration (from $4.35 \pm$ 0.52 to $14.36 \pm 1.82 \mathrm{ng} / \mathrm{mL}$ ) (Fig. 1).

As can be seen in Fig. 1, the rate of increase in the concentration of free forms of molecules is commensurate with the factor by which the concentration of cells containing membrane-bound forms of the molecules rises.

An increase in the concentration of free adhesion molecules is less significant compared to the increase in membrane-bound molecule contents. It can be assumed that the formation of free pool of intercellular adhesion molecules occurs through cell activation and expression of the genes of membrane molecules and is followed by shedding. We have previously demon- strated that a similar pattern is characteristic of the differential clusters and apoptosis and lectin ligands [21, 22].

An increase in the blood SCD54 and sCD62L levels is associated with an increase $(p<0.05-0.001)$ in the contents of circulating lymphocytes and segmented neutrophils without left deviation (Table 1).

An increase in the sCD54 and SCD62L concentrations occurs against the background of the rise of the content of mature $\mathrm{T}$ cells, predominantly activated HLADRII, and cytotoxic CD8+ ones (Table 2).

An increase in the serum sCD54 and sCD62L levels is associated with a twofold increase in the IL-10 content. The content of IFN- $\gamma$ rises when the selectin ligand concentration increases (Table 3 ).

It was found that, when the blood level of sCD54 and $\mathrm{SCD} 62 \mathrm{~L}$ increases, the concentrations of serum IgE decrease significantly from $102.09 \pm 21.37$ to $32.79 \pm 7.85$ and from $117.08 \pm 22.98$ to $62.08 \pm$ $12.80 \mathrm{IU} / \mathrm{mL}$. This pattern was not observed for other classes of immunoglobulins (IgM, IgG, and $\operatorname{IgA}$ ). Therefore, an increase in the activity of cellular cooperation and migration together with a rise in the content of membrane-bound and free adhesion molecules contributes to the reduction of the activity of reaginic reaction. It can be assumed that increased IgE synthesis is achieved through the insufficient cellular cooperation between the immunocompetent cells, including the neutrophils and activated $\mathrm{T}$ lymphocytes (Figs. 2, 3).

Free calcium-dependent cellular adhesion protein was not interrelated with any of the studied classes of immunoglobulins (Fig. 4).

An increase in the sCD54 concentration is accompanied by the rise of the contents of IgA CIC (from $5.62 \pm 1.50$ to $8.32 \pm 1.12 \mathrm{~g} / \mathrm{L}, p<0.05), \operatorname{IgM} \mathrm{CIC}$ (from $5.23 \pm 1.70$ to $8.69 \pm 1.05 \mathrm{~g} / \mathrm{L}, p<0.01$ ), and IgG CIC (from $2.11 \pm 0.50$ to $4.15 \pm 0.48 \mathrm{~g} / \mathrm{L}, p<$ 0.001 ) (Fig. 5). 
Table 1. The correlation between the contents of free intercellular adhesion receptors and blood cells

\begin{tabular}{|c|c|c|c|c|c|c|}
\hline $\begin{array}{c}\text { Blood cells, } \\
10^{9} \text { cell } / \mathrm{L}\end{array}$ & $\begin{array}{c}\mathrm{sCD} 54< \\
133.46 \pm \\
5.25 \mathrm{ng} / \mathrm{mL}\end{array}$ & $\begin{array}{c}\mathrm{sCD} 54> \\
290.88 \pm \\
9.90 \mathrm{ng} / \mathrm{mL}\end{array}$ & $\begin{array}{c}\mathrm{sCD} 62 \mathrm{~L}< \\
3.85 \pm \\
0.41 \mathrm{ng} / \mathrm{mL}\end{array}$ & $\begin{array}{c}\mathrm{sCD} 62 \mathrm{~L}> \\
14.36 \pm \\
1.82 \mathrm{ng} / \mathrm{mL}\end{array}$ & $\begin{array}{c}\mathrm{sCD} 324< \\
0.16 \pm \\
0.02 \mathrm{ng} / \mathrm{mL}\end{array}$ & $\begin{array}{c}\mathrm{sCD} 324> \\
0.89 \pm \\
0.04 \mathrm{ng} / \mathrm{mL}\end{array}$ \\
\hline Leukocytes & $6.40 \pm 0.43$ & $7.85 \pm 0.31^{*}$ & $6.23 \pm 0.45$ & $9.68 \pm 0.54 * * *$ & $8.43 \pm 0.77$ & $7.38 \pm 0.72$ \\
\hline Lymphocytes & $1.76 \pm 0.17$ & $2.95 \pm 0.28 * *$ & $1.65 \pm 0.19$ & $3.60 \pm 0.61 * * *$ & $2.70 \pm 0.37$ & $2.28 \pm 0.30$ \\
\hline Monocytes & $0.52 \pm 0.05$ & $0.62 \pm 0.10$ & $0.66 \pm 0.15$ & $0.52 \pm 0.09$ & $0.85 \pm 0.19$ & $0.60 \pm 0.14$ \\
\hline $\begin{array}{l}\text { Banded } \\
\text { neutrophils }\end{array}$ & $0.51 \pm 0.12$ & $0.41 \pm 0.07$ & $0.25 \pm 0.07$ & $0.32 \pm 0.07$ & $0.36 \pm 0.11$ & $0.45 \pm 0.17$ \\
\hline $\begin{array}{l}\text { Segmented } \\
\text { neutrophils }\end{array}$ & $2.40 \pm 0.28$ & $3.55 \pm 0.20^{* *}$ & $3.48 \pm 0.36$ & $5.10 \pm 0.26^{* * *}$ & $3.75 \pm 0.53$ & $3.53 \pm 0.47$ \\
\hline Neutrophils & $2.91 \pm 0.22$ & $3.96 \pm 0.14^{* *}$ & $3.73 \pm 0.35$ & $5.42 \pm 0.24^{* * *}$ & $4.11 \pm 0.61$ & $3.98 \pm 0.57$ \\
\hline Eosinophils & $0.25 \pm 0.06$ & $0.41 \pm 0.07^{* *}$ & $0.19 \pm 0.05$ & $0.16 \pm 0.05$ & $0.22 \pm 0.04$ & $0.20 \pm 0.06$ \\
\hline
\end{tabular}

Significance of the differences FROM the low sCD level: * $p<0.05 ; * * p<0.01 ; * * * p<0.001$.

Table 2. The correlation between the contents of free intercellular adhesion receptors and lymphocyte phenotypes

\begin{tabular}{|c|c|c|c|c|c|c|}
\hline $\begin{array}{c}\text { Phenotypes, } \\
10^{9} \text { cell } / \mathrm{L}\end{array}$ & $\begin{array}{c}\mathrm{sCD} 54< \\
133.46 \pm \\
5.25 \mathrm{ng} / \mathrm{mL}\end{array}$ & $\begin{array}{c}\mathrm{sCD} 54> \\
290.88 \pm \\
9.90 \mathrm{ng} / \mathrm{mL}\end{array}$ & $\begin{array}{c}\mathrm{sCD} 62 \mathrm{~L}< \\
3.85 \pm \\
0.41 \mathrm{ng} / \mathrm{mL}\end{array}$ & $\begin{array}{c}\mathrm{sCD} 62 \mathrm{~L}> \\
14.36 \pm \\
1.82 \mathrm{ng} / \mathrm{mL}\end{array}$ & $\begin{array}{c}\mathrm{sCD} 324< \\
0.16 \pm \\
0.02 \mathrm{ng} / \mathrm{mL}\end{array}$ & $\begin{array}{c}\mathrm{sCD} 324> \\
0.89 \pm \\
0.04 \mathrm{ng} / \mathrm{mL}\end{array}$ \\
\hline CD3+ & $0.54 \pm 0.07$ & $0.74 \pm 0.12^{* *}$ & $0.58 \pm 0.12$ & $0.91 \pm 0.14^{* * *}$ & $0.55 \pm 0.08$ & $0.44 \pm 0.06$ \\
\hline CD71+ & $0.48 \pm 0.09$ & $0.60 \pm 0.10^{* *}$ & $0.44 \pm 0.11$ & $0.57 \pm 0.13^{* *}$ & $0.57 \pm 0.13$ & $0.45 \pm 0.09$ \\
\hline CD25+ & $0.52 \pm 0.05$ & $0.62 \pm 0.10^{* * *}$ & $0.34 \pm 0.05$ & $0.54 \pm 0.05^{* * *}$ & $0.45 \pm 0.06$ & $0.41 \pm 0.06$ \\
\hline HLADRII & $0.53 \pm 0.06$ & $0.90 \pm 0.16^{* * *}$ & $0.28 \pm 0.05$ & $0.77 \pm 0.03^{* * *}$ & $0.43 \pm 0.07$ & $0.45 \pm 0.07$ \\
\hline CD10+ & $0.46 \pm 0.06$ & $0.58 \pm 0.08^{* *}$ & $0.28 \pm 0.05$ & $0.68 \pm 0.06^{* * *}$ & $0.59 \pm 0.18$ & $0.56 \pm 0.10$ \\
\hline CD4+ & $0.44 \pm 0.05$ & $0.69 \pm 0.11^{* * *}$ & $0.50 \pm 0.14$ & $0.62 \pm 0.07 * *$ & $0.49 \pm 0.05$ & $0.40 \pm 0.06$ \\
\hline CD8+ & $0.45 \pm 0.06$ & $0.93 \pm 0.12^{* * *}$ & $0.37 \pm 0.10$ & $1.05 \pm 0.17^{* * *}$ & $0.47 \pm 0.07$ & $0.42 \pm 0.06$ \\
\hline CD16+ & $0.54 \pm 0.15$ & $0.75 \pm 0.12^{* *}$ & $0.64 \pm 0.10$ & $0.86 \pm 0.17^{* * *}$ & $0.57 \pm 0.11$ & $0.44 \pm 0.10$ \\
\hline CD95+ & $0.48 \pm 0.07$ & $0.60 \pm 0.08^{* *}$ & $0.35 \pm 0.08$ & $0.71 \pm 0.03^{* * *}$ & $0.52 \pm 0.14$ & $0.39 \pm 0.09$ \\
\hline
\end{tabular}

See Table 1 for designations.

The same pattern is characteristic of L-selectin. An increase in the $\mathrm{SCD} 62 \mathrm{~L}$ content occurs together with the rise of the levels of IgA CIC (from $3.31 \pm 0.90$ to $5.34 \pm 0.89 \mathrm{~g} / \mathrm{L}, p<0.05$ ), IgM CIC (from $3.43 \pm 0.88$ to $5.54 \pm 1.05 \mathrm{~g} / \mathrm{L}, p<0.05$ ), and $\mathrm{IgG} \mathrm{CIC} \mathrm{(from}$ $0.80 \pm 0.30$ to $2.93 \pm 1.15 \mathrm{~g} / \mathrm{L}, p<0.001$ ) (Fig. 6).
However, when the concentration of the SCD324 calcium-dependent cellular adhesion protein increases, the levels of IgA CIC, IgM CIC, and IgG CIC remain almost unchanged $(4.91 \pm 0.74$ and $4.25 \pm 0.70 \mathrm{~g} / \mathrm{L})$, $(6.75 \pm 0.79$ and $5.35 \pm 0.73 \mathrm{~g} / \mathrm{L})$, and $(4.42 \pm 0.89$ and $4.12 \pm 0.82 \mathrm{~g} / \mathrm{L}$ ), respectively (Fig. 7).

Table 3. The correlation between the contents of free intercellular adhesion receptors and cytokines

\begin{tabular}{l|c|c|c|c|c|c}
\hline \multicolumn{1}{c|}{ Cytokines, } & $\mathrm{sCD} 54<$ & $\mathrm{sCD} 54>$ & $\mathrm{sCD} 62 \mathrm{~L}$ & $\mathrm{sCD} 62 \mathrm{~L}>$ & $\mathrm{sCD} 324<$ & $\mathrm{sCD} 24>$ \\
$\mathrm{pg} / \mathrm{mL}$ & $133.46 \pm$ & $290.88 \pm$ & $3.85 \pm$ & $14.36 \pm$ & $0.16 \pm$ & $0.89 \pm$ \\
& $5.25 \mathrm{ng} / \mathrm{mL}$ & $9.90 \mathrm{ng} / \mathrm{mL}$ & $0.41 \mathrm{ng} / \mathrm{mL}$ & $1.82 \mathrm{ng} / \mathrm{mL}$ & $0.02 \mathrm{ng} / \mathrm{mL}$ & $0.04 \mathrm{ng} / \mathrm{mL}$ \\
\hline $\mathrm{IL}-2$ & $7.41 \pm 0.64$ & $10.52 \pm 0.48$ & $59.06 \pm 2.67$ & $55.64 \pm 2.55$ & $50.44 \pm 4.33$ & $57.63 \pm 3.00$ \\
$\mathrm{IL}-6$ & $20.72 \pm 0.47$ & $24.84 \pm 1.34$ & $4.40 \pm 0.91$ & $3.52 \pm 0.67$ & $4.15 \pm 0.56$ & $3.89 \pm 0.71$ \\
$\mathrm{IL}-10$ & $0.07 \pm 0.01$ & $0.15 \pm 0.02 * * *$ & $16.80 \pm 4.32$ & $31.13 \pm 5.07 * * *$ & $20.85 \pm 12.81$ & $26.97 \pm 19.81$ \\
IFN- $\gamma$ & $13.95 \pm 2.21$ & $10.22 \pm 1.80$ & $53.28 \pm 7.70$ & $80.60 \pm 12.26^{* *}$ & $82.21 \pm 17.94$ & $78.09 \pm 20.02$ \\
\hline
\end{tabular}

See Table 1 for designations. 
The identified pattern of a parallel increase in the contents of the type I free intercellular adhesion molecules, as well as in the levels of selectin and IgA, IgM, and $\mathrm{IgG}$ circulating immune complexes, suggests that free receptors do not affect the formation of the circulating immune complexes. Most likely, the rise in the content of these free forms inhibits initiation of the regulatory immune reaction, including the antibody formation.

\section{DISCUSSION}

Thus, an increase in the blood levels of the sCD54 and $\mathrm{SCD} 62 \mathrm{~L}$ adhesion molecules is associated with the rise of the contents of circulating lymphocytes and functionally active segmented neutrophils. Neutrophils are primarily the first effector cells that produce a wide range of cytokines and can modulate the functional activity of monocytes and lymphocytes [2325]. The influence of neutrophils on the total lymphocyte count and their activation is mediated by growth factors, vasomotor amines, and activation of the complement system [26] and prostaglandins [27-29]. The expression of the CD40, CD80, CD86, and HLA genes determines the ability of neutrophils to act as antigen-presenting cells [30, 31]. Neutrophilic granulocytes migrate to the pathology focus at a very early stage of a disease; in addition, as with any other pathological process, neutrophilic granulocytes first appear in the focus of pathology [32-35]. Neutrophils are capable of intraphagosomal and extracellular degranulation; they can regulate the processes of preventive inflammation and immune response at the autocrine and paracrine levels [36-39]. The neutrophil products involved in controlling vascular permeability include $\mathrm{C} 3 a, \mathrm{C} 5 a$, histamine, which acts through $C 3 a$ and $C 5 a$, leukotrienes, thromboxane $\mathrm{A} 2$, kinins, and angiotensin II [33]. Certainly, it can be assumed that the increased proportion of neutrophils in the total circulating cell structure, which reflects the activation of cellular migration, affects the efficiency of cellular cooperation and coordination of the immune response.

The increase in the adhesion molecule content is accompanied by an increase in the levels of activated HLADRII-type cells. It is known that HLA products enable cells to differentiate between its own and foreign materials, whereas $T$ helpers recognize type II molecules [40, 41]. Therefore, the increase in the free pool of cellular adhesion molecules reflects activation of the antigen recognition process, which involves intensification of the migration processes and the rise of the total pool of circulating and recirculating lymphocytes and concentrations of HLADRII and CD8+. However, the increase in the total content of circulating lymphocytes and in that of the two T-cell phenotypes described above are incommensurable (an increase in the T-cell count is within $0.47-0.49 \times$ $10^{9}$ cell/L, whereas the total lymphocyte count is

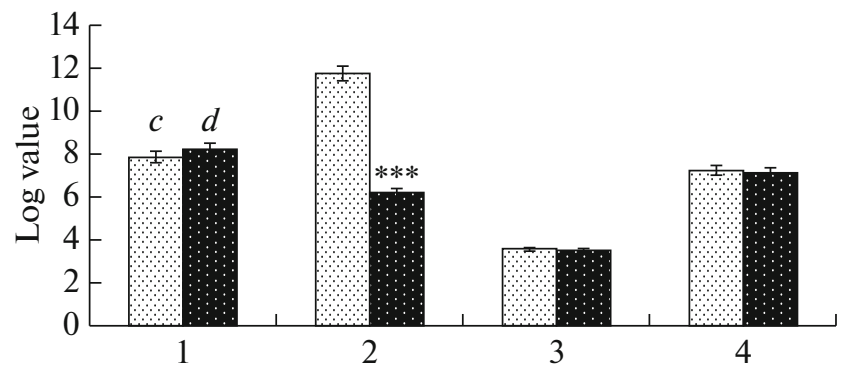

Fig. 2. The levels of immunoglobulins at low and high sCD62L levels. The abscissa shows the levels of: $1, \operatorname{IgA} ; 2$, $\mathrm{IgE} ; 3$, IgM; 4 , IgG; $c$, low sCD62L level; $d$, high sCD62L level; *** significant differences from the first group, $p<$ 0.001 .

almost doubled, reaching 1.19-1.95 $\times 10^{9}$ cell/L). This suggests that, of two identified regulatory functions of the adhesion molecules (activation of the cel-

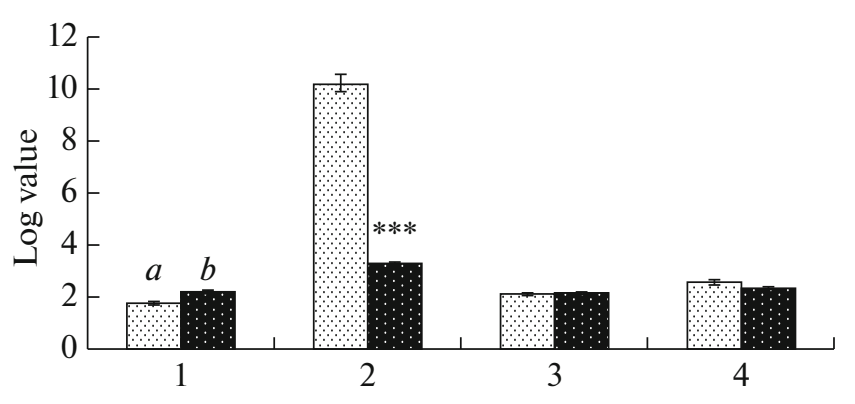

Fig. 3. The levels of immunoglobulins at low and high sCD54 levels. The abscissa shows the levels of: $1, \operatorname{IgA} ; 2$, IgE; $3, \operatorname{IgM} ; 4$, IgG; $a$, low sCD54 level; $b$, high sCD54 level; $* * *$ significant differences from the first group, $p<$ 0.001 .

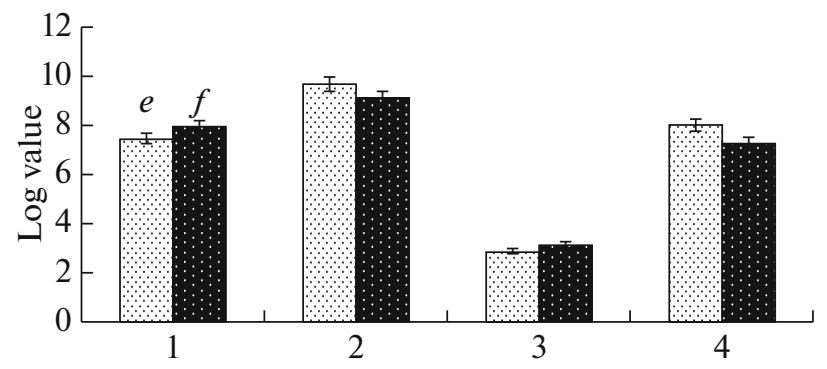

Fig. 4. The levels of immunoglobulins at low and high sCD324 levels. The abscissa shows the levels of: $1, \operatorname{IgA} ; 2$, IgE; 3, IgM; 4, IgG; $e$, low sCD324 level; $f$, high sCD324 level. 


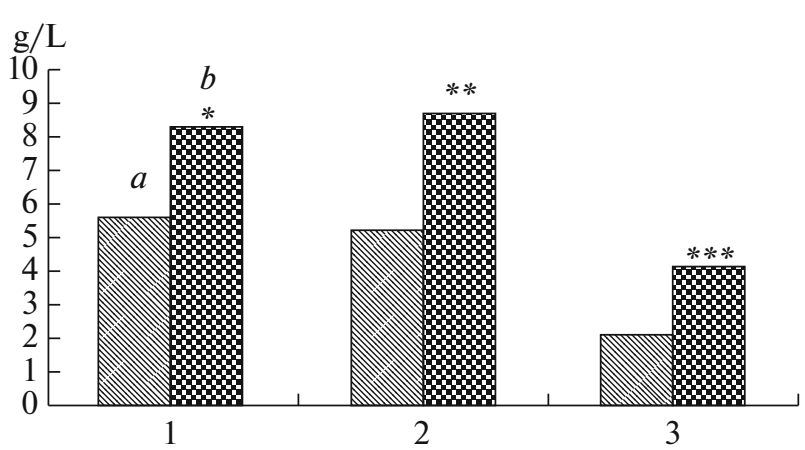

Fig. 5. The contents of Ig A, IgM, and IgG CIC at low and high sCD54 levels. The abscissa shows the levels of: $1, \operatorname{IgA}$ CIC; 2, IgM CIC; 3, IgG CIC; $a$, low sCD54 level; $b$, high sCD54 level. Significant differences from the low sCD54 level: ${ }^{*} p<0.05 ;{ }^{* *} p<0.01 ;{ }^{* * *} p<0.001$.

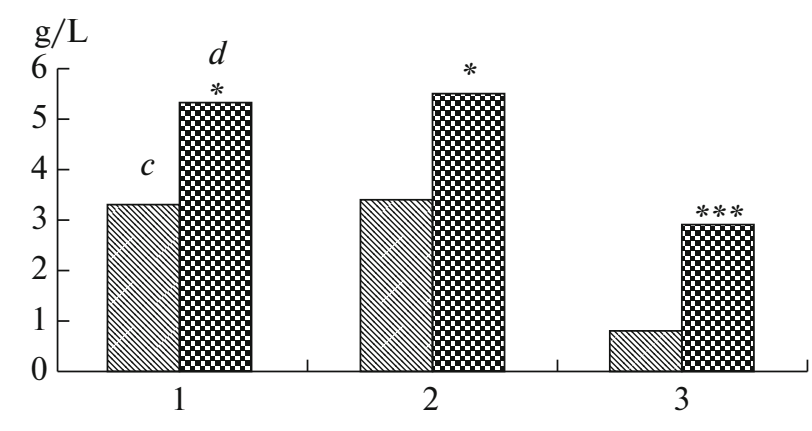

Fig. 6. The contents of $\operatorname{Ig} \mathrm{A}, \operatorname{IgM}$, and IgG CIC at low and high sCD62L levels. The abscissa shows the levels of: 1, IgA CIC; 2, IgM CIC; 3, IgG CIC; $c$, low sCD62L level; $d$, high sCD62L level. Significant differences from the low sCD62L level: ${ }^{*} p<0.05 ;{ }^{* * *} p<0.001$.

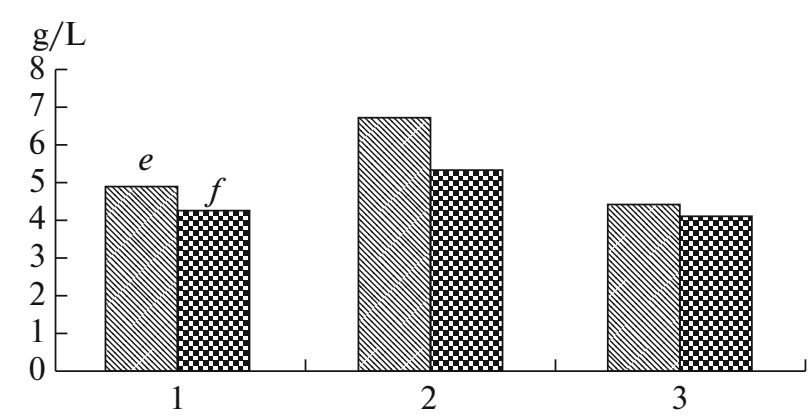

Fig. 7. The contents of Ig A, IgM, and IgG CIC at low and high sCD324levels. The abscissa shows the levels of: $1, \operatorname{IgA}$ CIC; 2 , IgM CIC; 3 , IgG CIC; $e$, low sCD324 level; $f$, high sCD324 level. lular migration and antigen recognition), the activation of migration and recirculation processes is the primary reaction.

It has been first found that the increase in free circulating adhesion molecules is associated with the inhibition of secretion or accumulation of immunoglobulin E. It can be assumed that the activation of $\operatorname{IgE}$ class switching may be triggered by insufficient activity of cellular migration and antigen recognition. The causes and conditions for activation of IgE production are unknown, although there is enough evidence for the association between IgE and stress hormones and the correlation between the deficit of secretory antibodies and IgE [42, 43]. IgE are distinguished by a certain specificity which allows recognition of antigen conformation and underlies the strongest antibodydependent cellular cytotoxicity response [44, 45]. A special feature of a reaginic reaction is that the activity of immune response is manifold enhanced when it is accompanied by the activation of basophils, mast cells, and eosinophils, which produce the most potent complex of cytokines and vasomotor amines [43-45]. The new data on inhibition of the cell-cell interaction together with the increase in the level of free circulating adhesion molecules in response to activation of IgE antibody formation deserve special attention when explaining the causes and conditions of the development of hyperimmune response.

The data on the association between the increase in the membrane-bound and free adhesion molecule (CD54, CD62L) contents and IL-10 level are relevant. The increase in IL-10 concentration reflects the activation of inhibitory mechanisms which include the inhibition of the expression of the genes of activating molecules. IL-10 production requires a higher level of stimulation than that of other cytokines does; in addition, the threshold required for IL-10 to affect T cell proliferation is significantly higher than that needed for the maintenance of cell population [46-48]. This inhibitory mechanism of regulation indicates the accumulation of extracellular pool of receptors.

\section{CONCLUSIONS}

Therefore, the increase in the blood free adhesion molecule content results from the rise of the level of immunocompetent cells which contain the membrane-bound forms of these molecules.

The increase in the contents of membrane-bound and circulating adhesion molecules is associated with activation of cellular migration and increased blood level of neutrophils and lymphocytes.

The concentration of lymphocytes containing membrane-bound and free forms of adhesion molecules increases together with the increase in the level of activated HLADRII and CD8+ phenotypes of T lymphocytes. 
A decrease in the expression of the genes of immunocompetent cell adhesion molecules determines intensification of the immune reaction by switching to IgE production.

The content of free adhesion molecules rises together with the increase in the blood IL-10 level; in other words, it occurs in parallel with the inhibition of expression of the genes of activating molecules. This inhibitory mechanism indicates detrimental accumulation of extracellular receptor pool.

\section{ACKNOWLEDGMENTS}

The study was performed in the framework of the Programme for Basic Research on the following topics: "The Ratio between the Membrane and Extracellular Forms of Differential Molecules in Regulation of the Systemic Immune Response" (project no. 04092014-0216); project coordinator, Professor L.K. Dobrodeeva, DSc; "The role of the extracellular pool of adhesion molecules and short peptides in the development and outcome of adaptive reactions" (project no. 0409-2016-0013); project coordinator, A.V. Samodova, $\mathrm{PhD}$, of the laboratory of regulatory mechanisms of the immune system of the Institute of Physiology of Natural Adaptations.

\section{COMPLIANCE WITH ETHICAL STANDARDS}

Conflict of interests. The authors declare that they have no conflict of interest.

Statement of compliance with standards of research involving humans as subjects. Before entering the study, the participants gave written informed consent. The study was performed in accordance with the World Medical Association Declaration of Helsinki on Ethical Principles for Medical Research (2000).

\section{REFERENCES}

1. Roitt, I., Brostoff, J., and Male, D., Immunology, London: Mosby, 1996, 4th ed.

2. Fuller, G.M. and Shields, D., Molecular Basis of Medical Cell Biology, Stamford, CT: Appleton and Lange, 1998.

3. Andrews, J.L., Kim, A.C., and Hens, J.R., The role and function of cadherins in the mammary gland, Breast Cancer Res., 2012, vol. 14, no. 1, p. 203.

4. Ley, K., Laudanna, C., Cybulsky, M.I., and Nourshargh, S., Getting to the site of inflammation: the leukocyte adhesion cascade updated, Nat. Rev. Imunol., 2007, vol. 7, no. 9, p. 678.

5. Colditz, I.G., Schneider, M.A., Pruenster, M., and Rot, A., Chemokines at large: in-vivo mechanisms of their transport, presentation and clearance, Thromb. Haemostasis, 2007, vol. 97, no. 5, p. 688.

6. Godin, C., Caprani, A., Dufaux, J., and Flaud, P., Interactions between neutrophils and endothelial cells, J. Cell Sci., 1993, vol. 106, no. 2, p. 441.
7. Granger, D.N. and Kubes, P., The microcirculation and inflammation: modulation of leukocyte-endothelial cell adhesion, J. Leukocyte Biol., 1994, vol. 55, no. 5 , p. 662.

8. Capra, F., De Maria, E., Lunardi, C., et al., Serum level of soluble intercellular adhesion molecule 1 in patients with chronic liver disease related to hepatitis $\mathrm{C}$ virus: a prognostic marker for responses to interferon treatment, J. Infect. Dis., 2000, vol. 18, no. 2, p. 425.

9. Zheng, R.-D., Su, Y.-Y., Lu, Y.-H., et al., Alteration of intercellular adhesion molecule-1 expression in the liver and serum level of HBV DNA in chronic hepatitis B patients after interferon treatment, Afr. J. Microbiol. Res., 2011, vol. 5, no. 10, p. 1211.

10. Fasching, P., Veitl, M., Rohac, M., et al., Elevated concentrations of circulating adhesion molecules and their association with microvascular complications in insulin-dependent diabetes mellitus, J. Clin. Endocrinol. Metab., 1996, vol. 81, no. 12, p. 4313.

11. Rothlein, R., Mainoff, E.A., Czajkowski, M., et al., A form of circulating ICAM-1 in human serum, J. Immunol., 1991, vol. 147, no. 11, p. 3788.

12. Babaev, A.A., Knyazev, D.I., Kravchenko, G.A., et al., Soluble oligomers of adhesion molecules CD50 and CD18 in human blood serum, Immunologiya, 2011, vol. 32, no. 2, p. 69.

13. Novikov, V.V., Baryshnikov, A.Yu., and Karaulov, A.V., Soluble forms of membrane immune cells of the immune system, Immunologiya, 2007, vol. 28, no. 4, p. 249.

14. Novikov, V.V., Karaulov, A.V., and Baryshnikov, A.Yu., Rastvorimye formy membrannykh belkov kletok immunnoi sistemy (Soluble Types of Membrane Proteins of Immune Cells), Moscow: Med. Inf. Agentstvo, 2008.

15. Novikov, V.V., Soluble forms of differentiated antigens of hemopoietic cells, Gematol. Transfuziol., 1996, no. 6, p. 40.

16. Heidenreich, K.A., de Vellis, G., and Gilmore, P.R., Functional properties of the subtype of insulin receptor found on neurons, J. Neurochem., 1988, vol. 51, no. 3, p. 878.

17. Kitamura, T., Mosaic analysis of insulin receptor function, J. Clin. Invest., 2004, vol. 113, no. 2, p. 2090.

18. Costs, E., Lima, M., Alves, J., et al., Inflammation, Tcell phenotype, and inflammatory cytokines in chronic kidney disease patients under hemodialysis and its relationship to resistance to recombinant human erythropoietin therapy, J. Clin. Immunol., 2008, vol. 28, no. 3, p. 268.

19. Seidelin, G.B., Vainer, B., and Horn, T., Circulating L-selectin levels and enthelial CD 34 expression in inflammatory bowel disease, J. Gastroenterol., 2009, no. 10, p. 1854.

20. Aleksandrov, A.V., Dzhekson, A.M., and Rumyantsev, A.G., Analysis of the modulation mechanism of intercellular adhesion molecules ICAM, Iтmиnologiya, 1997, no. 1, p. 4.

21. Samodova, A.V. and Dobrodeeva, L.K., Effect of extracellular receptors pool on the active immune response, Proc. X Conf. "Fundamental and Applied Sciences Today," North Charleston, December 26-27, 2016, North Charleston, Sc: CreateSpace, 2016, vol. 2, p. 9. 
22. Samodova, A.V. and Tsypysheva, O.B., The ratio of the extracellular pool of receptors and the level of immune responses in people living in the Polar regions, Ekol. Chel., 2005, no. 12, p. 21.

23. Cascao, R., Rosario, H.S., and Fonseca, J.E., Neutrophils: warriors and commanders in immune mediated inflammatory diseases, Acta Reumatol. Port., 2009, vol. 34 , no. 2, p. 313 .

24. Nekhaev, S.G. and Grigor'ev, S.G., Polymorphonuclear leukocytes as a system of antidendotoxic protection of the organism, Immunologiya, 2010, vol. 31, no. 3, p. 116.

25. Balashova, S.N. and Patrakeeva, V.P., Relationship of the functional activity of neutrophilic granulocytes and peripheral blood lymphocytes in people living in Arctic regions, Vestn. Ural. Med. Akad. Nauki, 2014, vol. 48, no. 2 , p. 114.

26. Wright, D.C. and Callin, G.I., A functional differential of human neutrophil granules, J. Immunol., 1977, vol. 119, p. 238.

27. Becker, T.L. and Henson, P.M., In vitro studies of immunologically induced secretion of mediators from cell sand related phenomena, Adv. Immunol., 1973, vol. 17, p. 94.

28. Henson, P.M., Pathologic mechanism in neutrophilmediated injury, Am. J. Pathol., 1972, vol. 68, no. 3, p. 593.

29. Holden, N.J., Williams, J.M., Morgan, M.D., Challa, A., et al., ANCA-stimulated neutrophils release BLyS and promote B cell survival: a clinically relevant cellular process, Ann. Rheumatol. Dis., 2011, vol. 70, no. 12, p. 2229.

30. Gavin, P., Sandilands Zubir, A., Perry, N., et al., Young cross-linking of neutrophil CD11b results in rapid cell surface expression of molecules required for antigen presentation and T-cell activation, Immunology, 2005, vol. 114, no. 3, p. 354.

31. Megiovanni, A.M., Francoise, S., Macarena, R., et al., Polymorphonuclear neutrophils deliver activation signals and antigenic molecules to dendritic cells: a new link between leukocytes upstream of T lymphocytes, $J$. Leukocyte Biol, 2006, vol. 79, no. 5. p. 977.

32. Hen, Y., Wu, H., Winnall, W.R., and Loveland, K.L., Tumour necrosis factor- $\alpha$ stimulates human neutrophils to release preformed activin A, Immunol. Cell Biol., 2011, vol. 89, no. 8, p. 889.

33. Letner, G.Z., Lunch, J.M., Betz, S.J., and Henson, P.N., Human neutrophil-derived platelet activating factor, J. Immunol., 1980, vol. 124, no. 2, p. 646 .

34. Conssens, L.M. and Werb, Z., Inflammatory cells and cancer: think different, J. Exp. Med., 2001, vol. 193, no. 6, p. 23.
35. Di Carlo, E., Forni, G., and Musiant, P., Neutrophyls is the antitumoral immune response, Chem. Immunol. Allergy, 2001, vol. 83, p. 182.

36. Pretswich, R.J., Errington, F., and Hatfield, P., The immune system-is it relevant to cancer development, progression and treatment, Clin. Oncol., 2008, vol. 20, p. 101.

37. Nothan, C., Neutrophils and immunity: challenges and port unities, Nat. Rev. Immunol., 2006, vol. 6, no. 6, p. 173.

38. Yang, D., Chen, Q., Chertov, O., and Oppenheim, J.J., Human neutrophil defensins selectively chemoattract naive $\mathrm{T}$ and immature dendritic cells, $J$. Leukocyte Biol., 2000, vol. 68, no. 1, p. 945.

39. Baumhueter, S., Dybdal, N., Kyle, C., and Lasky, L.A., Global vascular expression of murine CD34, a sialomucine-like endothelial cell ligand for 1selectin, Blood, 1994, vol. 84, p. 2554.

40. Zinkernagel, R.M., Callahan, G.N., Althage, A., et al., On the thymus in the differentiation of $\mathrm{H}-2$ self-recognitions by T-cells: Evidence for dual recognition? $J$. Exp. Med., 1978, vol. 148, no. 3, p. 882.

41. Katz, D.N., The role of the histocompatibility complex in lymphocyte differentiation, Cold Spring Harbor Symp. Quant. Biol., 1977, vol. 41, p. 611.

42. Dobrodeeva, L.K., The content of immunoglobulin E in the blood serum of people living in European Russia, Ekol. Chel., 2010, no. 5, p. 3.

43. Shtaborov, A.A. and Levanyuk, A.I., Interaction of general and local immune responses in persons born and living in the North, Ekol. Chel., 2010, no. 10, p. 42.

44. Barbee, R.A., Halomen, M., Lebowitz, M., and Burrows, B., Distribution of IgE in a community population sample: correlation with age, sex and allergen test reactivity, J. Allergy Clin. Immunol., 1981, vol. 68, no. 2, p. 106.

45. Maurer, D., Ebner, C., and Reininger, B., The high affinity receptor (FceRI) mediates IgE-dependent allergen presentation, J. Immunol., 1995, vol. 154, no. 12 , p. 6285 .

46. Dhus, O., Bunk, S., and von Aulock, S., Hermann Corinna IL-10 release requires stronger toll-like receptors 4-triggering than TNF, Immunology, 2008, vol. 213, no. 8, p. 621 .

47. Palmer, M.J., Mahajan, V.S., Chen, D.J., et al., Signaling thresholds govern heterogeneity in IL-7-receptor-mediated responses of naïve $\mathrm{CD} 8^{+} \mathrm{T}$ cells, Immunol. Cell Biol., 2011, vol. 89, no. 5, p. 581.

48. Wilk, C.M., Wei, S., Wong, L., et al., Dual biological effects of the cytokines interleukin-10 and interferon- $\gamma$, Immunol. Immunother., 2011, vol. 60, no. 11, p. 1529.

Translated by I. Matiulko 